\title{
SPATIAL MODELLING OF URBAN GROWTH AND URBAN INFLUENCE: APPROACH OF REGIONAL DEVELOPMENT IN DEVELOPING ECONOMY (INDIA)
}

\author{
Md. Julfikar ALI ${ }^{1)}$, Deepika VARSHNEY ${ }^{2)}$ \\ 1) Aliah University, Kolkata, India, 2) Aligarh Muslim University, Aligarh, India
}

\begin{abstract}
Urbanization and regional development are closely associated. Allocation of higher and lower order facilities and specialization of business influence urban growth which diffuses its benefits to the surrounding countryside. Subsequently, socio-economic development of the region comes into being. The continuous increase of urban size can not be sustained rather declining growth will certainly set in long run. Optimum level of its growth depends on the capacity of an urban centre to provide required facilities to the people in fair manner. Hierarchical growth of urban centres in association with location of civic amenities induces regional development in hierarchical dimension which is the common problem in developing economy. Subsequently, few of the urban centres are having large number of facilities while others are lacking corresponding to their population size. Formulation of pragmatic planning model is the rescue of wiping out such problems. It is an attempt to analyze the hierarchical growth of urban centres associated with their functional potentiality and diffusion of urban developmental impulses to the surrounding rural part. Further, it proposes a model for developing economy like India to solve the problem of regional variations of development. Besides, it examines the adequacy and inadequacy of facilities in the urban centres and puts forward planning recommendations, so that a balanced regional development would be achieved by not leaving any rural part out of the zone of functional influence of urban centre.
\end{abstract}

Key Words: urban growth, regional development, urban influence, functional weightage.

\section{Introduction}

India is predominantly a rural country where most of the people lives in villages, hamlets or a small group of huts (Verma 2006). It is noticeable that, India is experiencing rapid rate of population growth and urbanization. In 2001, it recorded 27.78 per cent urbanization which was much lower than the world average 47 per cent, Asian average 38 per cent, but little higher than Bangladesh i.e., 25 per cent and Sri Lanka i.e., 23 per cent (United Nations 2001). The process of urbanization is a complex system which comprises a set of interdependent entities, objectives, activities, infrastructure and land (Tiwari et al. 1986) and however it is the testimony of socio-economic and cultural development of a region or human group (Ali et al. 2008). In India, the process is the consequences of industrialization (Bhagat 2002). Therefore, it is equipped with the potentialities of development of the non-agricultural sectors (Ali et al. 2007). Urban growth is occurred due to the movement of people from- rural area to towns, smaller towns to bigger towns or cities and peripheral village to towns. Such a movement is generated due to the pull factors which attract immigrants towards urban centres and push factors which cause outmigration (Ahmad et al.,2006). Urban centres with location of seats of government, 
education, medical, financial and industrial units radiate growth impulses outward and subsequently bring significant economic change in the region (Mandal 2000). Besides, they provide a variety of highly centralized services for the surrounding rural part, like, marketing of agricultural products, supply of fertilizers, engineering goods, agricultural implements which are important for regional development (Hoselitz 1971). In due course of time, specialization of business is generated in the urban centres and later, the fruits of its benefits diffused to the countryside (Lampard 1955). Therefore, the proper growth and development of urban centres is imperative for regional economic progress (Hoselitz 1971).

Urban centres do not grow in isolation, rather in response to changing situation (Thakur 2002). Urban growth is the out come of concentration of population in response to the availability of diverse amenities and facilities in the urban centre. Subsequently, urban population is found distributed among the settlements of varying sizes from smaller towns to giant cities (Pascione 2001) as per their functional importance. Small towns might have been villages but with time due to the increasing agglomeration economies they gradually become urban centres by virtue of their nodality, function and services - local as well as central (Verma 2006). In its evolving pattern, small and intermediate towns grow slowly as compared to large cities in early phase of urbanization, but in latter phase, small towns grow as the consequence of congestion and crowding in large and intermediate towns. Therefore, growth of towns follows the cycle of urbanization from the phases of smaller town, intermediate town and primate city (Geyer and Kontuly 1993). It is worthy to mention that continuous increase of urban size can not be sustained. The decline in growth rate will certainly set in with increasing size of urban centres in long run (Mills and Becker 1986). However, their natural growth should be allowed in order to reap the benefits of their growth momentum. But the optimality of urban size is elusive and finally finds its own in due course of time (Bhagat 2005). The optimum level of its growth depends upon the capacity of the urban centre in providing all required facilities to the people in fair manner. High capacity enhances the level of optimum while huge inflow of migrants than the capacity causes over burden on the civic finances for providing basic amenities. Such a stage of over-urbanization gives rise to all evils in urban centre, i.e., housing problem, water scarcity, lack of medical facility, unemployment, increasing poverty and suicide, spread of slums and squatters, increase of beggars and pavement dwellers, delinquency, snatching, kidnapping, traffic congestion and overcrowding, atmospheric pollution and so on. These problems are the outcome of continuum process of urbanization mainly seen in very few big cities of India (Verma 2006, Mandal 2000). Such a situation is the reflection of optimum growth of an urban centre and thereafter declination of its growth begins.

The need of mitigation of such an undesirable urban phenomena led to come up of urban planning. It is usually formulated with an objective to attain the beauty of urban environment and making it more attractive for convenient living (Abercrombie 1945) and to encompass wellbeing as well as welfare of the people (Stamp 1941). It is surprising that, the tradition of urban planning in India is as old as the Indus Valley Civilization, Mohenjodaro and Harappa (Possehl 1979).

\section{Urbanization Scenario in Asian-African Countries}

The $20^{\text {th }}$ century is remarkable from the standpoint of human settlements. There is the unabated concentration of population in urban places of Asia and African countries. Europe experienced rapid urbanization in the $19^{\text {th }}$ century and in the early $20^{\text {th }}$ century. By 1995 , Africa and Asia were at highly comparable levels of urbanization, with about 35 per cent of their population being classified urban. Yet, both continents stood for high concentrations of world's population, most notably in Asia, which accounted for 60.4 per cent and 46.3 per cent 
respectively, of the world's total and urban population. By 2030, about 55 per cent of the world's urban population will be in Asia. What is also interesting is about 16 per cent will be in Africa, about equal to Europe and North America combined.

Asia and Africa will account for a heavy 86 per cent of all increases in the world's urban population in the next four decades. Africa's urban population will increase from the current 414 million to over 1.2 billion by 2050 , while Asia will increase from 1.9 billion to 3.3 billion. Over the next four decades through 2050, India will add another 497 million to its urban population; China 341 million; Nigeria 200 million; the United States 103 million; and Indonesia 92 million. The unprecedented rise in urban populations will pose new challenges, including shortages of food, jobs, housing, energy, infrastructure and a deterioration of the urban environment (United Nations Report 2012).

With free trade and globalization, along with the death of distance, prices of traded products have got almost equalized across the world. Thus, globalization has added further focus to the importance of the city level efficiency. The rapid economic growth of Asia in the last half century must be among the most spectacular periods of development in recorded human history. A common feature of Asian economic strategy has been the heavy concentration of economic activity in and around coastal regions. In Japan, infrastructure investment was concentrated in the Tokkaido region- the Tokyo-Nagoya-Osaka Corridor. More than 60 per cent of its urban population got concentrated in this region by 1970. In Republic of Korea, there was the development of urban infrastructure and transport in the Seoul-Pusan regions consequently by the mid of 1970s about 70 per cent of the Republic of Korean urban population resided here. Similar strategy was adopted for the development of Taipei-Kaohsing in Taiwan Province of China. The similar process of urban development and urbanization was followed by Singapore and "Hong Kong, China" as city states, JABOTABEK (the Jakarta region) in Indonesia, Bangkok in Thailand, Kuala Lumpur and environs in Malaysia, and finally in the coastal regions of China. As a result, a mega urban corridor stretching from Tokyo to Sydney through Seoul, Taipei, Shanghai, Hong Kong (China), Kuala Lumpur, Singapore and Jakarta has emerged (Mohan 2007). The Bangkok Metropolitan Area encompasses total area of 7, 761 $\mathrm{km}^{2}$ with total population of 10 million. By 2020, population is projected to grow to 30 and 100 million in Bangkok Metropolitan Area and Jakarta Metropolitan Region respectively (Yuen 2009). These countries achieved great economies of scale in the provision of urban infrastructure and services through the agglomeration variety of economic activities.

\section{Objectives}

Following basic objectives have been taken to pursue the present research work:

- $\quad$ to analyze the spatial distribution of population and socio-economic facilities,

- to make a hierarchical arrangement of urban centres,

- to delineate the zone of influence of urban centres,

- to establish the laws governing how urban centre grows and how their sphere of influence is increasing, and

- $\quad$ to make suggestive remarks for the proper growth and development of urban centres.

\section{Hypotheses}

Following general hypotheses have been formulated to infer the facts of urban growth and regional development: 
- $\quad$ population concentration is directly proportional to the functional importance of town,

- functional importance of town is the factor of its spatial expansion,

- $\quad$ higher order town with higher functional importance encompasses larger surrounding area under its influence.

\section{Data Base and Methodology}

To accomplish the above objectives as well as to ascertain the laws through testing above hypotheses, secondary information has been collected from different sources published by government. The data have been analyzed using different advanced statistical techniques to deduce and generalize the facts. To work out the ranking of towns on the basis of functional importance, it is necessary to assign a certain weight to all the facilities under study.

For this purpose, mean population threshold of all the facilities has been estimated as the population-function ratio which can be expressed as:

$$
\mathrm{mT}=\mathrm{P} / \mathrm{Nf}
$$

Where, $\mathrm{mT}=$ mean population threshold, $\mathrm{P}=$ total population, and $\mathrm{Nf}=$ total number of facility.

Functional weightage of facility has been estimated with following equation:

$$
\mathrm{WFi}=\mathrm{mTi} / \mathrm{mT} 1
$$

Where, $\mathrm{WFi}=$ estimated weightage of function ' $\mathrm{i}$ ', $\mathrm{mTi}=$ mean population threshold of ith function, and $\mathrm{mT} 1$ = lowest mean population threshold.

Functional importance of urban centre has been estimated with the equation as:

$$
\mathrm{Cl}=\sum_{\mathrm{i}=1}^{\mathrm{n}}(\text { Fui } \times \text { Whi })
$$

Where, $\mathrm{Cl}=$ centrality index or functional importance of a town, Fui = number of functional units of function 'i', and Whi = weightage of function 'i'.

Concentration ratio of facilities in different size group of towns has been examined using Gini's method of Coefficient of Concentration (Mahmood, 2002) which is as follows:

$$
\mathrm{Gi}=\frac{1}{10,000} \sum_{\mathrm{i}-1}^{N}\left(x_{i} \cdot y_{i}+1\right)-\left(x_{i}+1 \cdot y_{i}\right)
$$

Where, $\quad x_{i}=$ the cumulative percentage distribution of attribute $x$,

$y_{i}=$ the cumulative percentage distribution of attribute $y$,

$\mathrm{N}=$ the number of observations, and $\mathrm{Gi}=$ Gini's Coefficient Ratio

Scale of Gi Ratio:

$\mathrm{Gi}=$ Zero, is uniform distribution, and $\mathrm{Gi}=1.0$, is highest concentration.

Arithmetic equation of population projection is expressed as follows: 
 and $P_{2}$ ) and $t=$ time interval between the base year and the year of which projected population would be estimated.

The zone of influence of each town of hierarchical order has been delineated using modified quantitative technique devised by V.L.S. Prakash Rao (Lokhande and Pawar 2004) which is as follows:

$$
\begin{aligned}
& \text { S.I. }=\mathrm{TCA} / \mathrm{C} \\
& \mathrm{R}=\sqrt{\mathrm{TCA} / \mathrm{C}}
\end{aligned}
$$

Where, $\quad$ S.I. $=$ Sphere of Influence of central place $(\mathrm{sq} . \mathrm{km}$. $), \mathrm{TC}=$ Total Centrality score of central place, $A=$ Total area (sq. $\mathrm{km}$ ) of the study region, $C=$ Total centrality score of all central places, and $\mathrm{R}=$ Radius of circle indicating the sphere of influence $(\mathrm{km}$.

The causal relationship between dependent and independent variables has been examined using Karl Pearson's Technique of Correlation of Coefficient. In order to test the hypotheses and find out the level of significance of their correlation student's 't' test has been adopted.

To examine the adequacy or inadequacy of socio-economic facilities in relation to the existing population, following method of Relative Level of Urban Functional Ratio has been adopted.

$$
R_{i j}=\frac{P_{s}}{P_{t}} \times \frac{F_{t}}{F_{s}}
$$

Where, $\quad R_{i j}=$ relative level of urban function between 'a' town and study area, $P_{s}=$ urban population of study area, $P_{t}=$ population of the town, $F_{t}=$ functional importance of the town, $F_{s}=$ total urban functional importance of the study area. The ratio of function in a town more than 01 refers to the adequacy, while ratio less than 01 refers to the inadequacy of function in the town.

\section{Logical Approach of the Study}

The main thrust of the paper is to raise some ground realities related to the functional hierarchy of urban centres, their differential influence over surrounding countryside and regional disparities of socio-economic development which are the characteristic feature of developing economy like India. Such issues are the traditional and meaningless in developed economy where new economic policies like Export Processing Zone (EPZ), Special Economic Zone (SEZ), Exclusive Economic Zone (EEZ), e-Commerce and Advance Trading are practicing in full swing for the great achievement of urban growth, urban planning, enhancing employment level and consequent regional development. Though, India and other developing countries have adopted such policies but small size urban centres are still suffering from the lack of developmental facilities. Subsequently, their little radius of functional influence could not encompass the larger surrounding area of rural part. Therefore, the only solution to wipe out the regional inequalities of socio-economic development is to grow the small order of urban centres up to their full extreme potentiality so that they may radiate their developmental influence over the surrounding countryside. Such model is still imperative for the regional planning for socio-economic development in the developing economy. 
Md. Julfikar ALI , Deepika VARSHNEY
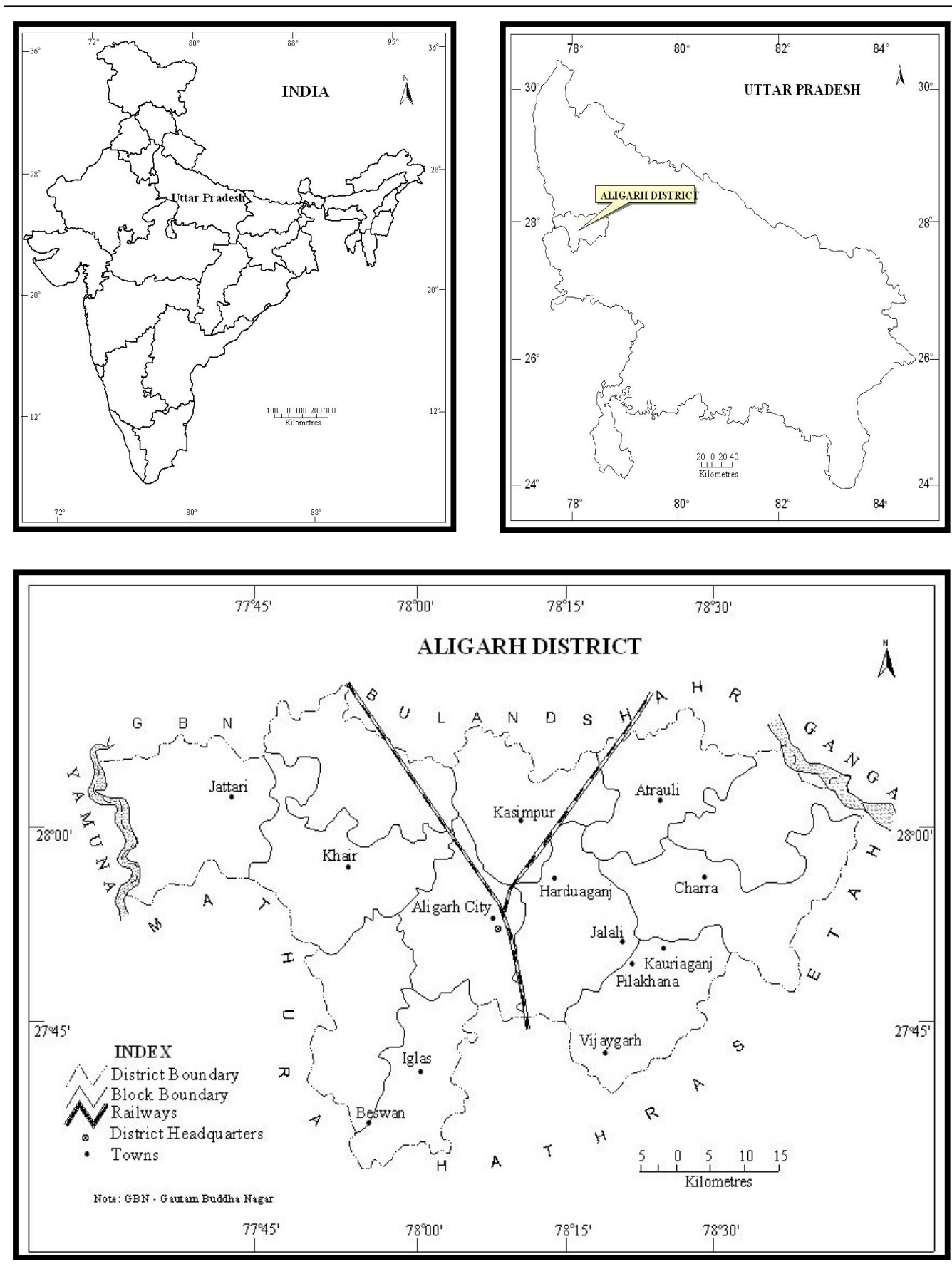

Fig. 1 - Position of Urban Centres in Aligarh district, 2012. 


\begin{abstract}
Area of Study
Aligarh district (Fig. 1) has been taken as the universe of present study located in the western part of Uttar Pradesh state of India. It lies within $27^{\circ} 34^{\prime} \mathrm{N}$ to $28^{\circ} 11^{\prime} \mathrm{N}$ latitudes and $77^{\circ} 29^{\prime} \mathrm{E}$ to $78^{\circ} 38^{\prime} \mathrm{E}$ longitudes. The fusion of historical and geographical elements in Aligarh district has given it a distinct personality. After British occupation in 1804, the district was formed. Introduction of railway line in March 1863 from Tundla to Aligarh has played an important role in the progress and prosperity of the district (Nevill 1926). The focal point of Aligarh district is Aligarh city from where communication arteries radiate to every corner of the district.
\end{abstract}

The district has a total area of $3670 \mathrm{sq}$. km. with a total population of 2992286 persons having 71 per cent rural and 29 per cent urban population (Census of India 2001). From the administrative view point, the district has been divided into 05 Tehsils namely Atrauli, Gabhana, Khair, Koil and Iglas comprising 1212 villages.

\title{
A Glance of Spatio-temporal Growth of Urban Population and Area
}

Growth of urban centres is closely linked with the political apparatus and considers political activity as the prime variable in the rise of cities (Mumford 1961). But the growth of urban centres in term of population and area is related with the different aspect of human life, such as economic development, technological advancement, political stability, cultural growth, social awareness and ecological setting. Therefore, no single or autonomous factor neither creates nor accelerates the growth of the existing urban centre. It is worthy to mention that the analysis of growth of urban population and area may assist to comprehend the spatio-temporal changes of rural-agrarian economy into urban-industrial one.

Table 1 reveals that Jattari town has recorded highest annual growth (i.e., 6.11 per cent) of urban population during 1991 over 1981. Jattari is followed by Iglas (5.17 per cent), Aligarh city (4.97 per cent). However, lowest annual growth has been recorded in Jalali town (1.23 per cent). But during the decade 1991-2001, highest annual growth has been recorded in Charra town i.e., 5.61 per cent leaving behind Jattari (2.79 per cent). Iglas and Aligarh remain in same position as in last decade with the annual growth of urban population 4.97 per cent and 3.92 per cent respectively. Further, it is evident from the same table (Table. 1) that almost all the towns of study area has been recorded to decline their annual growth rate of population during 1991-2001 from the decade 1981-1991 except Charra (i.e., 5.02 per cent in 1981-91 to 5.61 per cent in 1991-2001) and Pilakhana (i.e., 2.03 per cent in 1981-91 to 3.17 per cent in 19912001). In case of annual growth rate of urban area during 1981-91, only three towns i.e., Jalali, Harduaganj and Aligarh have registered their growth with 0.27 per cent, 0.42 per cent and 0.28 per cent respectively. However, during 1991-2001, most of the towns have registered a significant annual growth of urban area. Atrauli town has recorded highest growth rate i.e., 112.04 per cent followed by Beswan (14.5 per cent) and Kauriaganj (4.4 per cent). Among the 13 towns as identified by the Census of India, Khair, Kasimpur, Pilakhana, Iglas and Vijaygarh could not achieve any spatial expansion in both decades. It is again emerged out from the analysis that Atrauli shows a decline of annual growth of urban population in final decade (1991 -2001) from that of previous decade (1981-91), but recorded a splendid annual growth of urban area during 1991-2001 from that in last decade.

\section{Mean Population Threshold (MPT) and Functional Weightage of Facilities}

Socio-economic facilities are the prerequisite of socio-economic transformation of society from traditional to modern life. The provision of adequacy of such facilities is important 
Growth of Urban Population and Area, Aligarh District, 1981-2001

\begin{tabular}{|l|r|r|r|r|}
\hline \multirow{2}{*}{ Town } & \multicolumn{2}{|c|}{$\begin{array}{c}\text { Annual Growth of Population } \\
\text { (\%) }\end{array}$} & \multicolumn{2}{c|}{ Annual Growth of Area (\%) } \\
\cline { 2 - 5 } & $1981-1991$ & $1991-2001$ & $1981-1991$ & $1991-2001$ \\
\hline 1.Khair & 4.05 & 2.17 & 0 & 0 \\
\hline 2.Kasimpur & 1.60 & 1.54 & 0 & 0 \\
\hline 3.Jalali & 1.23 & 1.22 & 0.27 & 0 \\
\hline 4.Charra & 5.02 & 5.61 & 0 & 2.77 \\
\hline 5.Jattari & 6.11 & 2.79 & 0.42 & 2.0 \\
\hline 6.Harduaganj & 2.90 & 1.96 & 0 & 4.40 \\
\hline 7.Kauriaganj & 3.33 & 1.97 & 0 & 0 \\
\hline 8.Pilakhana & 2.03 & 3.17 & 0 & 0 \\
\hline 9.Iglas & 5.17 & 4.97 & 0 & 14.5 \\
\hline 10.Beswan & 2.35 & 0.9 & 0 & 0 \\
\hline 11.Vijaygarh & 3.13 & 2.5 & 0.28 & 112.04 \\
\hline 12.Atrauli & 2.86 & 2.45 & 3.92 & 0.87 \\
\hline 13.Aligarh & 4.97 & & 0.04 \\
\hline
\end{tabular}

Source: Population is based on data obtained from Census of India, 2001, Directorate of Census Operations, Uttar Pradesh.

for socio-economic development (Sharma, 1972). Generally, people have a tendency to concentrate in and around the points where different types of facilities are available. In the present analysis, in order to find out the relative difference of functional importance of each facility under study, their Mean Population Threshold (MPT) has been estimated. MPT is simply the average population served by each facility (Maithini 1986). Six broad types of facilities, i.e., education, health, communication, administration, finance and recreation, which are the essential requirements of human well-being and welfare, have been taken under study.

Table 2 exhibits the mean population threshold of all 28 facilities and their relative importance in the study area. Functional importance of each facility has been estimated by assigning an arbitrary weightage value of 01 to the facility having lowest MPT. The functional importance of other facility has been estimated by dividing their MPT by the lowest MPT in the list. Therefore, facilities comprising higher MPT have functionally higher importance and vice-versa. In another word, higher important facilities are fewer in number (rarely available) while it is reverse to the lesser important facilities. Among the education facilities i.e., medical college and university, are having highest MPT (i.e., 3,737,661 and 1,868,831 respectively) as well as functional importance (i.e., $31,675.09$ and 15,837.55 respectively) even among all the facilities in the district (Table 2). Primary school with MPT 1,727 has scored functional importance of 14.64 while family welfare centre and sub-centre with MPT 10,649, telephone connection with MPT 118 and agricultural credit societies with MPT 32,787 have scored functional importance of $90.24,1.00$ and 277.85 respectively.

\section{Distribution of Population and Facilities}

The analysis of spatio-temporal dynamism of phenomena is the main thrust of geographical 
Spatial Modelling of Urban Growth and Urban Influence: Approach of Regional Development in Developing Economy (India)

\begin{tabular}{|c|c|c|c|c|}
\hline \multicolumn{5}{|c|}{$\begin{array}{l}\text { Mean Population Threshold and Functional Weightage of Urban Facilities, } \\
\text { Aligarh District, } 2012\end{array}$} \\
\hline $\begin{array}{l}\text { Categories of } \\
\text { Facilities }\end{array}$ & Name of the Facility & $\begin{array}{c}\text { Number } \\
\text { of } \\
\text { facility }\end{array}$ & MPT & $\begin{array}{l}\text { Functional } \\
\text { Weightage }\end{array}$ \\
\hline \multirow{9}{*}{$\begin{array}{l}\text { 1) Educational } \\
\text { Institutes }\end{array}$} & Primary Schools & 2164 & 1727 & 14.64 \\
\hline & Middle/Junior Schools & 895 & 4176 & 35.40 \\
\hline & Secondary/Matriculation & 203 & 18412 & 156.04 \\
\hline & Senior Secondary Schools & 337 & 11091 & 93.99 \\
\hline & Adult Literacy Centre & 50 & 74753 & 633.50 \\
\hline & $\begin{array}{l}\text { Degree Colleges (Science, } \\
\text { Arts and Commerce) }\end{array}$ & 11 & 339787 & 2879.55 \\
\hline & University & 2 & 1868831 & 15837.55 \\
\hline & Medical Colleges & 1 & 3737661 & 31675.09 \\
\hline & Engineering Colleges & 8 & 467208 & 3959.39 \\
\hline \multirow{4}{*}{$\begin{array}{l}\text { 2) Recreational } \\
\text { Facilities }\end{array}$} & Stadium & 3 & 1245887 & 10558.36 \\
\hline & Cinemas & 20 & 186883 & 1583.76 \\
\hline & Public Library & 3 & 1245887 & 10558.36 \\
\hline & Reading Rooms & 3 & 1245887 & 10558.36 \\
\hline \multirow{6}{*}{ 3) Health Facilities } & Allopathic Hospitals & 18 & 207648 & 1759.73 \\
\hline & Ayurvedic Hospitals & 25 & 149506 & 1267.00 \\
\hline & Unani Hospitals & 3 & 1245887 & 10558.36 \\
\hline & Homeopathic Hospitals & 15 & 249177 & 2111.67 \\
\hline & $\begin{array}{l}\text { Family Welfare Centres/ } \\
\text { Sub-centres }\end{array}$ & 351 & 10649 & 90.24 \\
\hline & Primary Health Centres & 48 & 77868 & 659.90 \\
\hline \multirow{3}{*}{$\begin{array}{l}\text { 4) Financial and } \\
\text { Commercial Institutes }\end{array}$} & Nationalized Banks & 129 & 28974 & 245.54 \\
\hline & Non-Nationalized Banks & 29 & 128885 & 1092.26 \\
\hline & Agricultural Credit Societies & 114 & 32787 & 277.85 \\
\hline \multirow{5}{*}{$\begin{array}{l}\text { 5) Communication } \\
\text { and Administrative } \\
\text { Facilities }\end{array}$} & Post Offices & 372 & 10047 & 85.15 \\
\hline & Post and Telegraph Offices & 9 & 415296 & 3519.46 \\
\hline & PCOs & 826 & 4525 & 38.35 \\
\hline & Telephone Connections & 31695 & 118 & 1.00 \\
\hline & Police Stations & 27 & 138432 & 1173.15 \\
\hline 6)Cold Storage & Cold Storage & 59 & 63350 & 536.87 \\
\hline
\end{tabular}

Source: Calculation is based on data obtained from Sankhikiya Patrika (Statistical Bulletin), Aligarh District, 2012

Note: MPT= Mean population threshold, PCOs= Public call offices.

research. Likewise diverse physical, cultural, social and economic aspects, the distribution of population and facilities is not uniform across the region. But over the earth's surface, the nature of distribution of both population and facilities happens together, as both are 
interdependent to each other. People requires different facilities to sustain their socio-economic life as well as to fulfill needs and desires, while proper functioning of facilities depends on the size and purchasing power of patrons. Therefore, higher important facilities which are fewer in number available only in bigger size towns, while lower important facilities are available in both bigger as well as smaller size towns.

Table 3 reveals the distribution of 13 urban centres or towns in five categories according to their population size. Table 3 also indicates the total urban population and composite score of functional importance (total importance of all facilities in a town) in each size category. Aligarh is the biggest town in Aligarh district (study area) with its total projected population 983,220 persons in 2011 (79.41 per cent of total urban population in the district) and Composite Functional Score (CFS) of 340,497.39 (66.71 per cent of total urban functional importance), comes under the category of Class I towns in India. However, Atrauli $(55,725)$ is also single found in Class II town in the district having 04.50 per cent urban population and 11.10 per cent (CFS 56,656.22) urban functional importance. In the district, Class III towns (i.e., Jattari, Khair and Charra), Class IV towns (i.e., Kasimpur, Jalali, Harduaganj, Kauriaganj, Pilakhana and Iglas) and Class $\vee$ towns (i.e., Beswan and Vijaygarh) accommodate 7.63 per cent, 7.36 per cent and 1.10 per cent of total urban population of the district respectively, but they scored 8.62 per cent, 11.71 per cent and 1.85 per cent of urban functional importance respectively (Table 3 and Fig. 2). Table 3 further reveals the relative ratio of advantage of population and functional importance. Such an analysis is significant to estimate the probability of extension of a town in future. People flows towards the centre where there are ample opportunities of education, employment, medical, etc. as socio-economic pull factors. Therefore, a town having more functions but lesser population has more prospect of further growth. In this view, it may be argued that a town with ratio of advantage more than 01 or unity is supposed to have more functional importance in proportion to its existing population size, subsequently has an advantage of further expansion by attracting and accommodating more people. In contrary, towns with ratio less than 01 have lesser probability to be expanded. In the study area, Class I town i.e., Aligarh has scored the ratio of 0.84 (i.e., <1), while Class II town i.e., Atrauli has scored highest ratio of 2.47 followed by Class $V$ towns (1.69), Class IV towns (1.59) and Class III towns (1.13) (Table 3). It may be inferred that Aligarh urban centre has lesser probability of its further growth than the smaller size towns in the district. However, Atrauli has better prospect of its further growth in terms of both population and area consequent upon inmigration of people from surrounding rural part.

Again, irregular distribution of population and facilities among the size class of town has been analyzed based on the Gini's Coefficient of Concentration Method. The ratio of concentration of population in different size class of towns has been examined, where Gini's ratio of 0.79 ascertains that large number of urban population is disproportionately concentrated at few number of bigger size towns in the district, while large number of smaller size towns accommodates proportionally fewer population. However, Gini's value of 0.66 reveals that likewise population, facilities are also disproportionately concentrated in fewer bigger size towns while large number of smaller size towns is lacking of it. It is clear that the Gini's value of 0.57 determines unequal distribution of facilities in relation to the proportional distribution of population among size group of towns. In other words, both population and facilities are not concentrated in uniform proportion in different size of towns. It may be inferred that, higher concentration of facilities in a town leads to higher concentration of population. Therefore, the growth of towns in terms of availability of socio-economic facilities is subjected to the increase of population in that town as both are complementary to each other. It is emerged out from the above analysis that a town having higher availability of socio-economic facilities must have an excellent potentiality of inward pulling of people as well as the prospect of its further growth. 
Spatial Modelling of Urban Growth and Urban Influence: Approach of Regional Development in Developing Economy (India)

Table 3

Distribution of Population and Facilities among Classes of Town, Aligarh District, 2012

\begin{tabular}{|c|c|c|c|c|c|c|c|}
\hline $\begin{array}{c}\text { Class } \\
\text { of } \\
\text { Town }\end{array}$ & $\begin{array}{c}\text { Population } \\
\text { Size }\end{array}$ & $\begin{array}{l}\text { Name of } \\
\text { the Towns }\end{array}$ & $\begin{array}{c}\text { Total } \\
\text { Population } \\
\text { (P) }\end{array}$ & $\begin{array}{l}\text { Composite } \\
\text { Functio- } \\
\text { nal Score } \\
\text { (CFS) }\end{array}$ & $\begin{array}{c}\% \\
\text { Popula- } \\
\text { tion }\end{array}$ & $\begin{array}{c}\% \\
\text { of } \\
\text { CFS }\end{array}$ & $\begin{array}{c}\text { Ratio } \\
\text { of Ad- } \\
\text { vantage }\end{array}$ \\
\hline I & $\begin{array}{c}100000 \\
\text { and Above }\end{array}$ & Aligarh & 983220 & 340497.39 & 79.41 & 66.71 & 0.84 \\
\hline II & $\begin{array}{c}50000 \text { to } \\
99999\end{array}$ & Atrauli & 55725 & 56656.22 & 4.50 & 11.10 & 2.47 \\
\hline III & $\begin{array}{c}20000 \text { to } \\
49999\end{array}$ & $\begin{array}{c}\text { Jattari, } \\
\text { Khair and } \\
\text { Charra } \\
\end{array}$ & 94444 & 44005.47 & 7.63 & 8.62 & 1.13 \\
\hline IV & $\begin{array}{c}10000 \text { to } \\
19999\end{array}$ & $\begin{array}{l}\text { Kasimpur, } \\
\text { Jalali, } \\
\text { Harduaganj, } \\
\text { Kauriaganj, } \\
\text { Pilakhana } \\
\text { and Iglas }\end{array}$ & 91127 & 59778.72 & 7.36 & 11.71 & 1.59 \\
\hline V & $\begin{array}{c}5000 \text { to } \\
9999\end{array}$ & $\begin{array}{c}\text { Beswan and } \\
\text { Vijaygarh }\end{array}$ & 13583 & 9454.81 & 1.10 & 1.85 & 1.69 \\
\hline
\end{tabular}

Source: Computed from Table 4

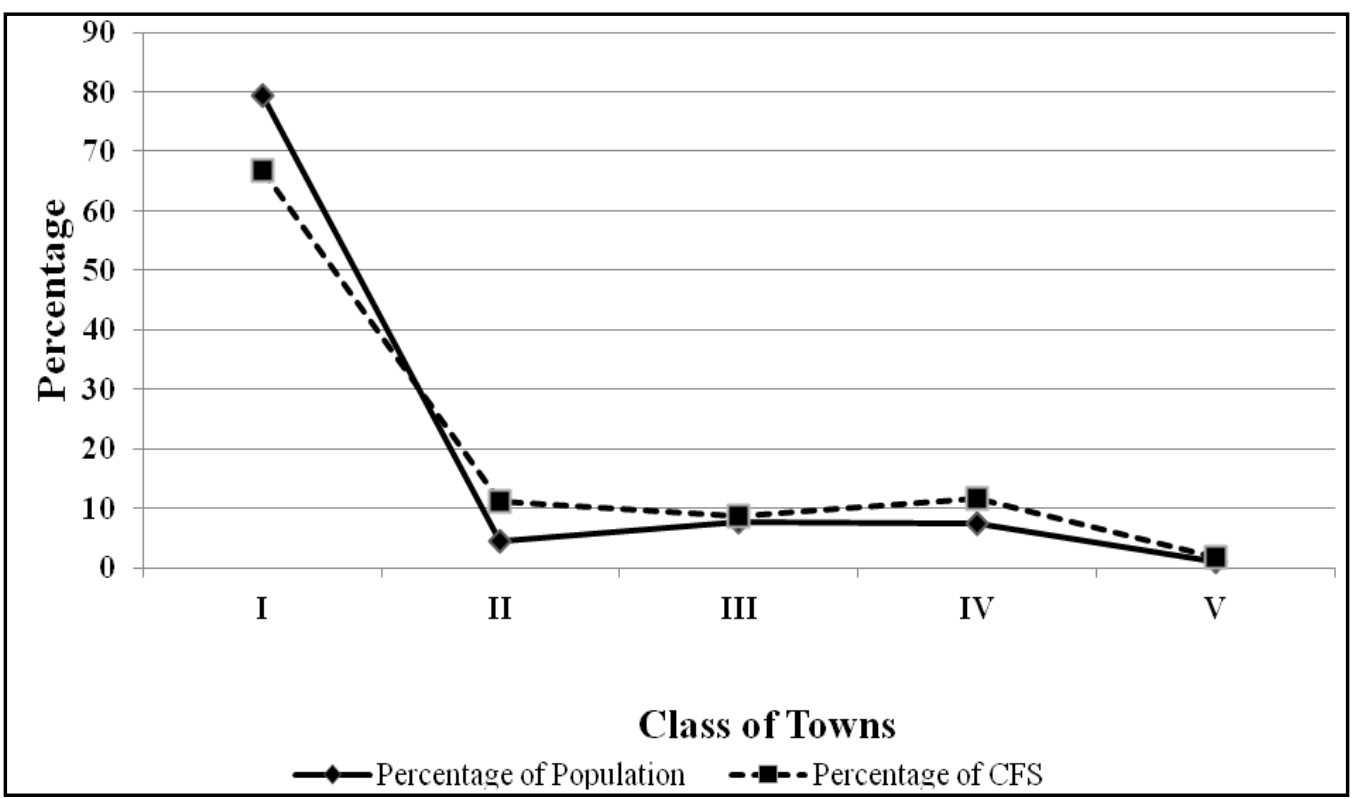

Fig. 2 - Percentage Distribution of Population and Function among Size Class of Towns, Aligarh District, 2012

Source: Based on authors' computation 


\section{Functional Importance of Urban Centres and their Hierarchy}

Functional importance is the sum of all the pulling factors available in a town. Therefore, higher functional importance having variety of both higher and lower order facilities exerts a greater pulling effect that attracts people towards an urban centre. Thus, a smaller town turns into a bigger urban centre progressively. Functional importance is the qualitative identity of a town, as it refers to the pulling gravity of later. Since the functional importance varies across town, their size of population and area also vary positively. Therefore, within a defined region, hierarchy of urban centres is emerged out in which towns are differing from each other in terms of their pulling gravity. Different terms used for the city indicate some hierarchical and functional variations among them (Thakur 1994). From this philosophical essence, it may be argued that a town having higher advantage of pulling factor has an equal advantage of more people to be in- migrated as well as accommodated in future. While in contrary, a town having lesser advantage of pulling factor has lesser possibility of being attracted by people to be in-migrated and accommodated there.

It is revealed that Aligarh city with functional importance $340,497.39$ stood at highest position accounting total population $9,83,220$ persons and 40.43 sq. $\mathrm{km}$ area (Table 4). Aligarh city is enjoying the status of district headquarter and have all the socio-economic facilities including a university, medical college etc. It is followed by the towns like, Atrauli with functional importance 56,656.22, Iglas with functional importance 29,520.91, Khair with functional importance 19,729.13. However, Pilahkana town having functional importance 435.05 stood at lowest position with population and area 13,280 persons and 12.62 sq.km. respectively.

Score of Functional Importance of Towns, their Population, Area and

Table 4 Sphere of Influence, Aligarh District, 2012

\begin{tabular}{|l|r|r|r|r|r|r|}
\hline \multicolumn{1}{|c|}{ Town } & $\begin{array}{c}\text { Functional } \\
\text { Importance }\end{array}$ & $\begin{array}{c}\text { Population } \\
\mathbf{( P )}\end{array}$ & $\begin{array}{c}\text { Area } \\
\mathbf{( s q} \\
\mathbf{k m} \text { ) }\end{array}$ & $\begin{array}{c}\text { Relative } \\
\text { Ratio of } \\
\text { Function }\end{array}$ & $\begin{array}{c}\text { Radius of } \\
\text { Influence } \\
\text { (R) in km. }\end{array}$ & $\begin{array}{c}\text { Sphere } \\
\text { of } \\
\text { Influence } \\
\text { (SI) in } \\
\text { sq. km. }\end{array}$ \\
\hline 1.Khair & 19729.13 & 36144 & 15.45 & 1.32 & 9.01 & 81.20 \\
\hline 2.Kasimpur & 10133.28 & 11876 & 09.0 & 2.07 & 6.46 & 41.70 \\
\hline 3.Jalali & 4220.12 & 19708 & 17.62 & 0.52 & 4.17 & 17.37 \\
\hline 4.Charra & 15500.34 & 35962 & 11.39 & 1.05 & 7.99 & 63.79 \\
\hline 5.Jattari & 8776.00 & 22338 & 7.50 & 0.95 & 6.01 & 36.12 \\
\hline 6.Harduaganj & 11099.31 & 14066 & 15.40 & 1.91 & 6.76 & 45.68 \\
\hline 7.Kauriaganj & 4370.05 & 12870 & 7.0 & 0.82 & 4.24 & 17.98 \\
\hline 8.Pilakhana & 435.05 & 13280 & 12.62 & 0.08 & 1.34 & 1.79 \\
\hline 9.Iglas & 29520.91 & 19325 & 3.0 & 3.71 & 11.02 & 121.49 \\
\hline 10.Beswan & 4791.51 & 5973 & 13.50 & 1.95 & 4.44 & 19.72 \\
\hline 11.Vijaygarh & 4663.30 & 7610 & 17.47 & 1.49 & 4.38 & 19.19 \\
\hline 12.Atrauli & 56656.22 & 55725 & 16.72 & 2.47 & 15.27 & 233.17 \\
\hline 13.Aligarh & 340497.39 & 983220 & 40.43 & 0.84 & 37.43 & 1401.32 \\
\hline
\end{tabular}

Source: Calculation is based on data obtained from Sankhikiya Patrika (Statistical Bulletin), Aligarh District, 2012. Population is based on data obtained from Census of India, 2001, Directorate of Census Operations, Uttar Pradesh.

Note: Projected population is calculated over the period of 2001 


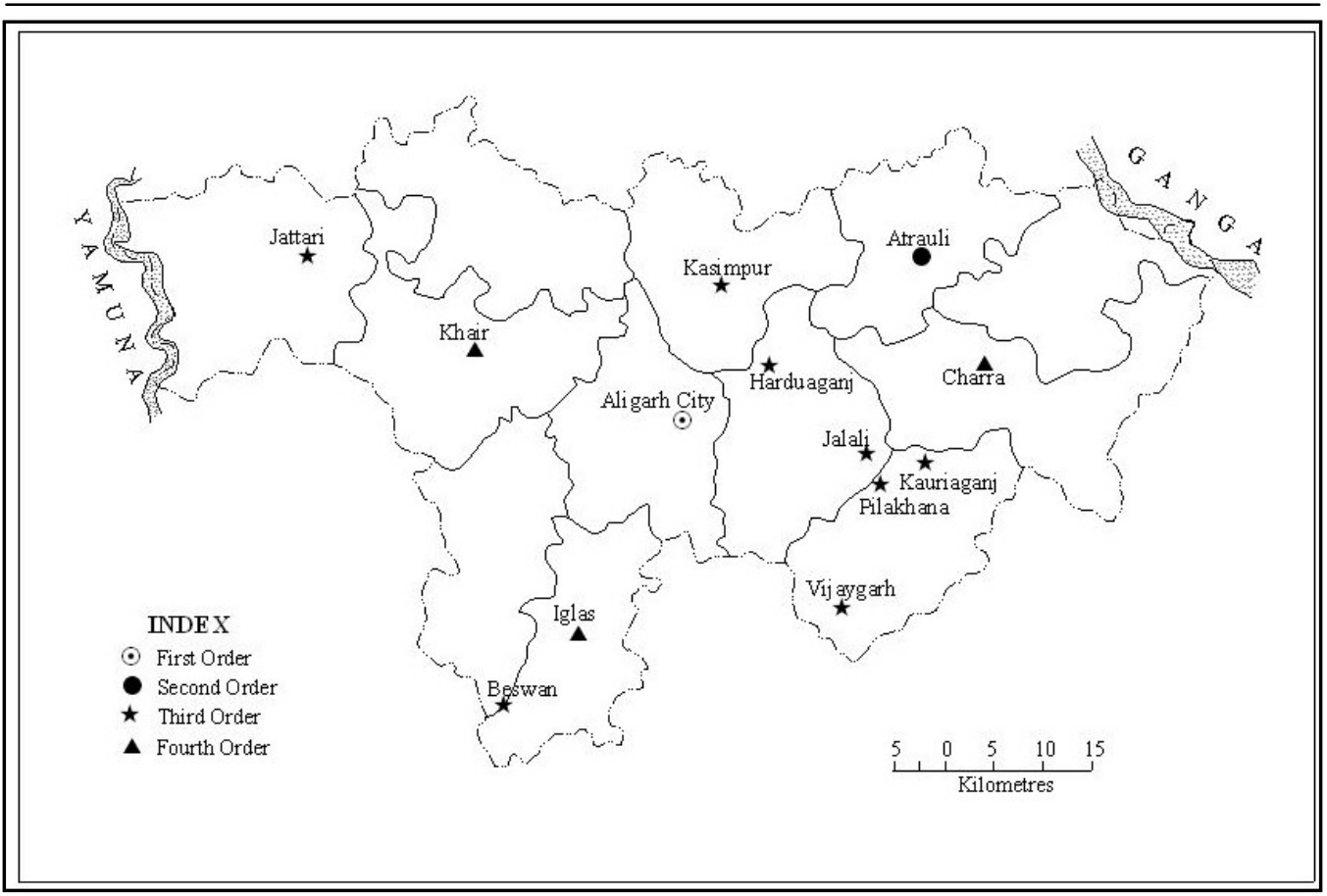

Fig. 3 - Hierarchical Order of Urban Centres in Aligarh District, 2012

Source: Based on Table 5

Hierarchy of Urban Centres, Aligarh District, 2012

Table 5

\begin{tabular}{|c|c|c|c|}
\hline $\begin{array}{l}\text { Order of } \\
\text { Hierarchy }\end{array}$ & $\begin{array}{l}\text { Range of Functional } \\
\text { Importance }\end{array}$ & $\begin{array}{c}\text { Number of } \\
\text { Towns }\end{array}$ & Name of the Towns \\
\hline First Order & More than 91740.38 & 01 & Aligarh \\
\hline $\begin{array}{l}\text { Second } \\
\text { Order }\end{array}$ & $91740.38-52479.41$ & 01 & Atrauli \\
\hline Third Order & 52 479.41-13 218.44 & 03 & Khair, Charra and Iglas \\
\hline Fourth Order & Less than 13218.44 & 08 & $\begin{array}{c}\text { Jalali, Kauriaganj, Kasimpur, } \\
\text { Pilakhana, Jattari, Harduaganj, } \\
\text { Vijaygarh and Beswan }\end{array}$ \\
\hline
\end{tabular}

Source: Computed from Table 4

Therefore, it is revealed that the relative difference of functional importance exists among the towns in the study area. Such a relative difference is the cause of emergence of functional hierarchy of urban centres (Nagia and Ahluwalia 2003).

Table 5 and Figure 3 reveal the hierarchical arrangement of urban centres into four orders starting from the first order or the highest order with highest functional importance to fourth order or the lowest order with lowest functional importance. Aligarh urban centre is the only one 
to come under the first order of functional hierarchy. Only one town i.e., Atrauli with functional importance ranging from $91,740.38$ to $52,479.41$ has been recognized under second order of hierarchy. However, three towns i.e., Iglas, Khair and Charra with functional score varying from $52,479.41$ to $13,218.44$ fall in third order of hierarchy. Rest eight towns i.e., Jalali, Kauriaganj, Pilakhana, Beswan, Jattari, Harduaganj, Kasimpur and Vijaygarh with functional score less than 13,218.44 are comprised under fourth order or lowest order of functional hierarchy of towns in the Aligarh district (Fig. 3).

\section{Zone of Influence of Urban Centre}

Each city forms the centre of a larger area and dominates over certain area which is actually the city's sphere of influence (Murphy 1974). Urban centres do not function in isolation, rather they provide goods and services to the area lying beyond the urban boundary. People from the surrounding area commute a town to avail the required facilities. But, people visit towns from a certain distance. The distance, which patrons willing to travel, depends on the importance of facility so that it should be the economy of the distance (Pawar and Lokhande 2001, Yasenovskiy and Hodgson 2007). Therefore, both importance of facility and the distance traveled by the patrons are positively related. Again, a town having large number and higher order of facilities is being visited by patrons from longer distance. In other words, a town with higher functional importance exerts an influence upon larger area of its surrounding (Lokhande and Pawar 2004). Such, an area surrounding the urban centre reveals the complexity of interaction and interdependence between town and surrounding rural area that is popularly known as functional region (Glasson 1978). It may be inferred that a town having higher functional importance covers larger zone of influence and vice-versa.

In the analysis by adopting V.L.S.Prakash Rao's modified method, the zone of influence of each urban centre has been delineated. Table 4 exhibits that Aligarh city exerts its influence up to $37.43 \mathrm{~km}$ and covers the area of $1,401.32 \mathrm{sq}$. $\mathrm{km}$. It is followed by Atrauli town with its radius of influence $15.27 \mathrm{~km}$. and sphere of influence $233.17 \mathrm{sq}$. km., Iglas with its radius $11.02 \mathrm{~km}$. and sphere of influence 121.49 sq. km. However, Pilakhana has been identified at bottom position in its functional influence with radius of $1.34 \mathrm{~km}$. and sphere of influence of $1.79 \mathrm{sq}$. $\mathrm{Km}$ (Table 4).

Figure 4 depicts the circular form of sphere of influence of urban centres at different hierarchical order. Higher order centres with higher functional importance encompasses larger dependent area within which dependent area of lower order centres come under. Aligarh city being a largest order urban centre in the district radiates its influence up to the highest distance from the centre with radius of influence $37.43 \mathrm{~km}$. Its influence reaches even outside the district boundary, i.e., northern, southern, south-eastern and south-western part and encompasses almost all the lower order urban centres including their dependent area (Fig. 4). It supports the philosophy that all lower order centres by providing lower order functions create rather smaller sphere of influence, but the inhabitants from such a sphere commute higher order centres to avail further higher order functions. Aligarh city is followed by Atrauli and Iglas urban centres with radius of influence $15.27 \mathrm{~km}$. and $11.02 \mathrm{~km}$. respectively. There is an overlapping of spheres of influence of Atrauli, Kasimpur, Harduaganj, Charra, Jalali, Kauriaganj and Pilakhana in east-central part of the district. It may be argued that this part of the district is sufficiently served by the closely located urban centres led to higher socio-economic development. Moreover, this part gets benefits of nearness of Aligarh city - the biggest urban as well as service centre. Pilakhana - lowest order centre with radius of influence $1.34 \mathrm{~km}$. comes under the zone of influence of Kauriaganj which also comes under the zone made by Jalali, though both are fourth or lowest order urban centres (Fig. 4). The same figure further depicts that the 


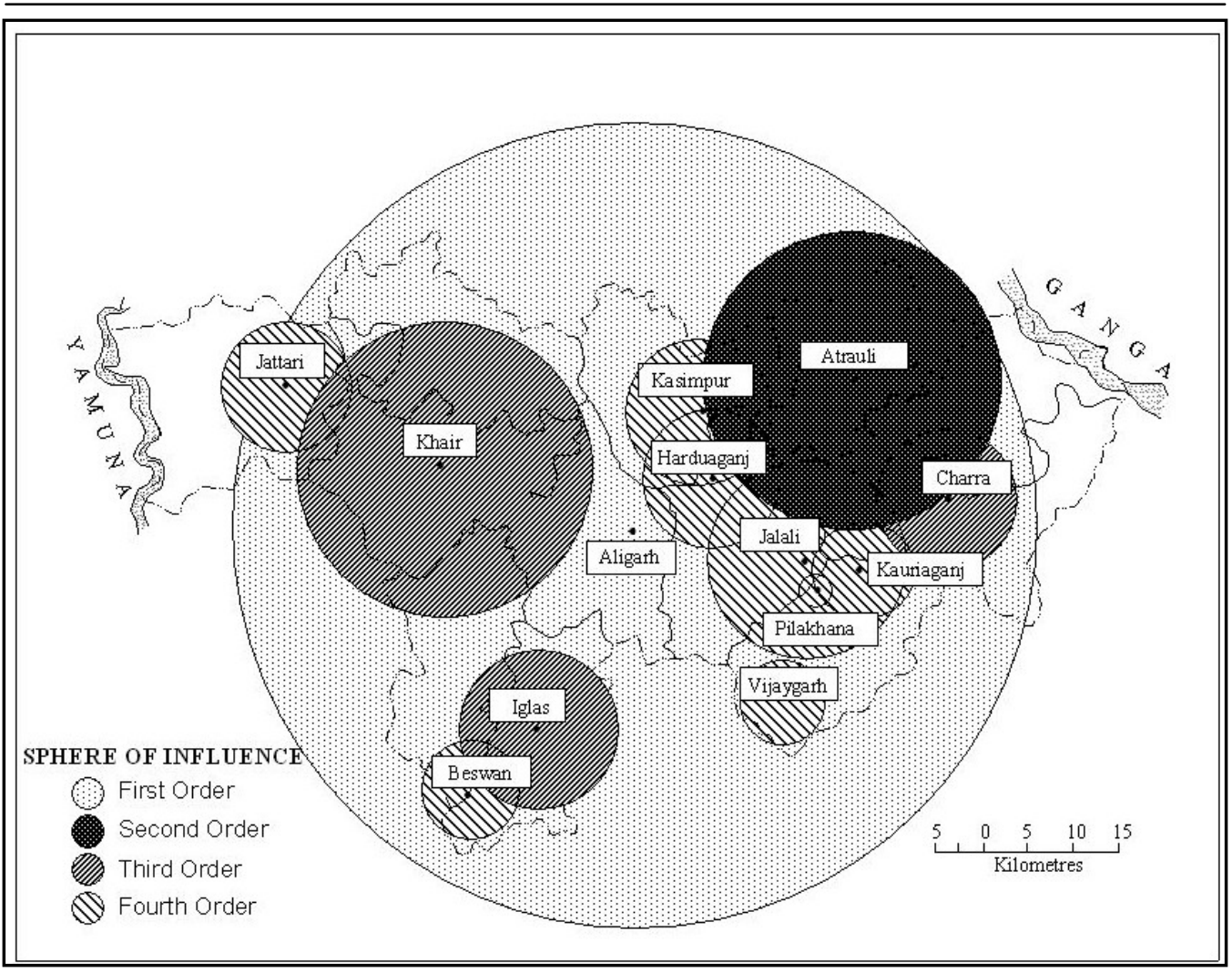

Fig. 4 - Sphere of Influence of Urban Centres of Aligarh District, 2012

(Based on modified method of V.L.S. Prakas Rao). Source: Based on Table 4.

extreme eastern and western part of the district do not comes under the sphere of influence of any urban centre. Such information is crucial for urban planning purpose in order to attain socio-economic change in these areas.

\section{Test of Hypotheses and Laws of Urban Growth}

In the present deductive approach of research, aforesaid general hypotheses have been formulated to be tested in particular area (Aligarh district) to establish the general laws of urban growth. Going through the quantitative analysis (Correlation Coefficient and 't' test) taking functional importance and population of urban centres as independent and dependent variables respectively, it is resulted that both are positively correlated with high degree of coefficient i.e., $r=0.992$. Their calculated ' $t$ ' value of 26.56 higher than the tabulated ' $t$ ' value of 3.11 at 11 degree of freedom reveals correlation is significant at 1 per cent level and assures that the hypothesis, 'population concentration is directly proportional to the functional importance of town' is accepted and it becomes a law of urban growth. It may be ascertained that higher functional importance of towns attracts large number of people to be concentrated which in turn leads to urban growth. Again, both higher functional importance as well as larger population together causes the spatial extension of urban centre. To investigate its ground reality, both functional importance and population as independent variables have been 
Md. Julfikar ALI , Deepika VARSHNEY

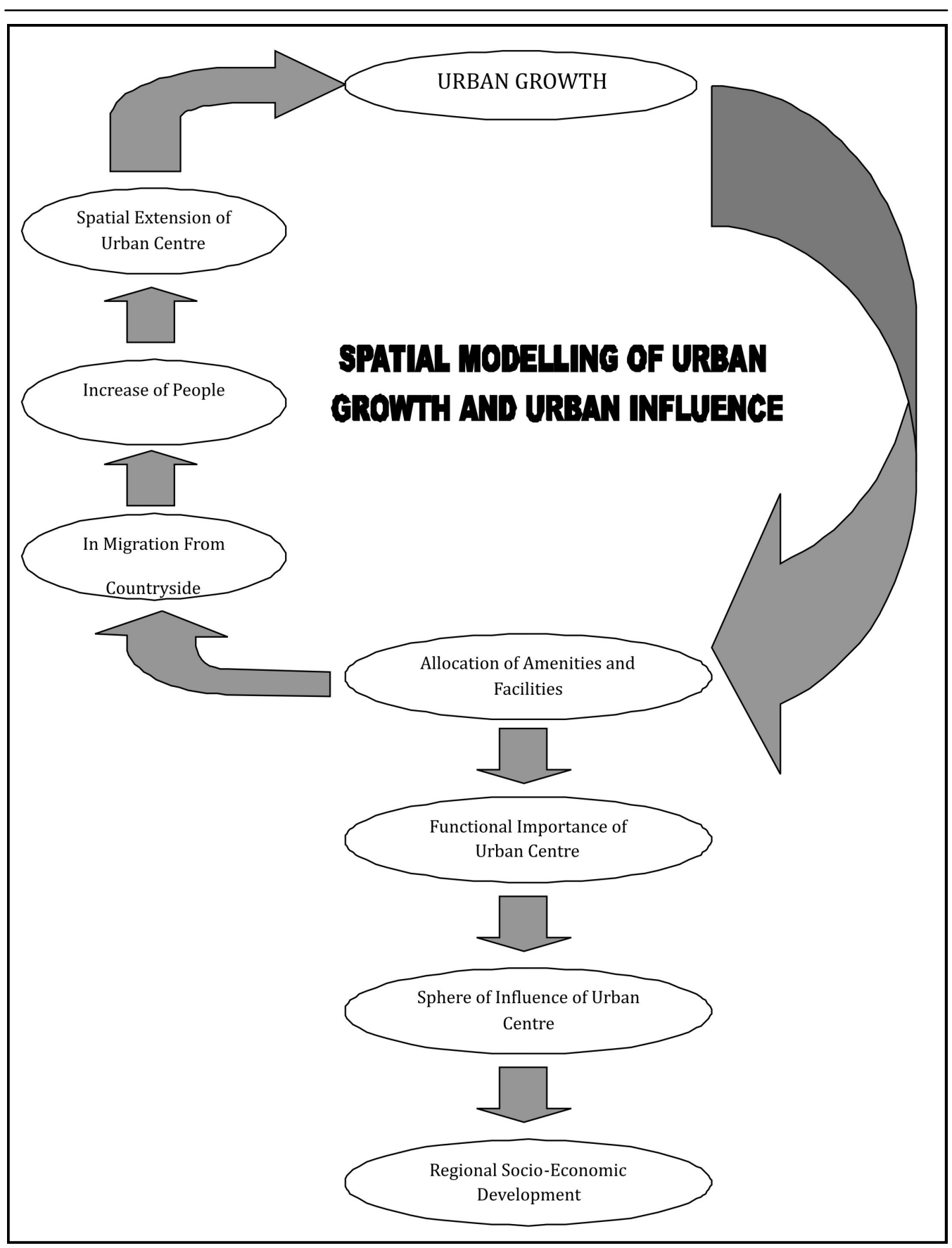

Fig.5 - Spatial Modelling of Urban Growth and Influence 
correlated with urban area (sq. $\mathrm{km}$.) as dependent variable. Their resultant $r=0.857$ (functional importance vs. area) and $r=0.871$ (population vs. area) significant at 1 per cent level at 11 degree of freedom accepts the hypothesis, 'functional importance of town has positive impact on its spatial extension' and 'population size is the function of area extension of urban centre' which further turned into the laws of urban growth. Another investigation has been done to test the causal relationship of functional importance of towns with their sphere of influence. It is observed that, functional importance as independent variable and sphere of influence of urban centre as dependent variable are positively correlated at higher degree of coefficient $(r=0.995)$ which is significant at 1 per cent level at 11 degree of freedom. It accepts the hypothesis, 'higher order towns with higher functional importance radiate influence over larger area' and again it turned into the law of urban growth. It may be argued that, proper balanced regional development would be attained only when no any part of countryside would remain out of the radius of functional influence of any urban centre. From the above quantitative examination, a spatial model of urban growth is emerged out as follows:

The model (Fig. 5) simply reveals how does an urban centre grow progressively into a bigger one and how much it is significant in regional socio-economic development. It comes to be true from the figure that the allocation of amenities and facilities primarily in a small size urban centre enhances its capability to attract people who in-migrate from countryside to have better opportunities of socio-economic advancement. Subsequently, more people are concentrated there leading to an increase of population size which is the catalytic effect of spatial extension of that urban centre. All these factors collectively resulted into an urban centre to grow progressively. It is important that, whenever a town turned into bigger one, it requires more facilities to be allocated to fulfill human needs and maintains better level of living which further attracts more people to in-migrate. But such a growth process continues till the urbanization finds its optimum level. Figure 5 further depicts that with the increase of allocation of facilities, the functional importance of town increases, subsequently the radius of influence as well as sphere of influence increases progressively. Therefore, such process results into the socioeconomic interface of the region.

\section{Functional Level Analysis and Planning Recommendation}

In the analysis of functional gap or functional level, the resultant relative ratio of 1.0 is meant for the balancing level of population in accordance to the existing facilities, however above or below of it refers to the urban centre is served adequately or inadequately respectively. Such an analysis has two objectives, i.e., first, to recommend for the additional facilities in inadequately served urban centres to reach at the standard level of population-function ratio (ratio of 1), and second, to identify the existing functional potentiality of urban centre to attract more migrants as well as possibility of its further growth. It is clear from the Table 4 that, among the inadequately served urban centres with relative ratio less than 1 , i.e., Jalali $(0.52)$, Kauriaganj (0.82), Pilakhana (0.08) and Aligarh city (0.84), Pilakhana has recorded least ratio of population and function. It reveals that the existing amenities and facilities are not sufficient for the present population size leading to larger stress of overburden of population on civic amenities and facilities. Pilakhana is followed by Jalali where also existing facilities does not correspond to the population size. Therefore, allocation of facilities must be made to raise its ratio at standard level of 1 from 0.52 which may widen its sphere of influence. Subsequently, socio-economic development of larger surrounding area would be achieved as a consequence. Kauriaganj and Aligarh urban centres are marginally below the standard ratio of 1 , therefore only few facilities may be provided there.

The analysis of relative ratio of functional level in Table 4 further reveals that Iglas with ratio 
3.71 has highest potentiality to attract much more population till the ratio adjusted to 1 , therefore possibility of fast growth. It is followed by Atrauli (2.47) which has bright possibility of further growth. Rest urban centres, i.e., Beswan (1.95), Khair (1.32), Harduaganj (1.91), Kasimpur (2.07), Vijaygarh (1.49), Jattari (0.95) and Charra (1.05) have potentiality of their growth by attracting people from surrounding area. Such an analysis of functional level of each facility of all the urban centres is more pragmatic as well as more specific for planning purposes, though not covered under the present study.

Keeping in view the goal of urban as well as regional socio-economic development in order to achieve some sort of human well-being, planning recommendations have been made as follows:

- Urban growth should be concrete in nature and should be accompanied by economic development of an area.

- $\quad$ The number of residents in an urban centre and facilities available for them must maintain equilibrium.

- The distribution of facilities should be in such a manner that their location may ensure easy accessibility in and around the areas of urbanization.

- To maintain the standard level of living, different types of higher as well as lower order facilities should be allocated in Pilakhana as it is one of the fourth order centres with least sphere of influence. In order to reap the regional socio-economic development, allocation of facilities is rather much imperative to enlarge its radius of influence.

- To encompass the eastern and western part of the district under the zone of urban functional influence (Fig. 4), more facilities especially of higher order should be allocated in Atrauli, Charra and Jattari towns. Consequently, the functional importance of these towns will sufficiently be increased and patrons from surrounding parts can easily avail developmental facilities. Such an approach may enable towns to achieve balanced regional development as a consequence of urban growth.

- $\quad$ Another significant planning approach should be made to connect all the urban centres by efficient transportation facility and finally, they should be connected with Aligarh city- the biggest order urban centre in the study area.

- Besides, a comprehensive planning policy should be taken to promote urban growth to such an extent that the functional importance of each centres of all hierarchical order may radiate into all corner of rural. Therefore, a significant influence can change their living standard and quality of life in the district.

\section{Conclusion}

Going through the above quantitative analysis, it is evident that the urban centres grow in hierarchical manner which are of different sizes. The distribution of both population and facilities are complementary to each other and they are highly concentrated in bigger size urban centres. Centres having large number of facilities as well as higher functional importance induce pulling effect and become a centre with greater chance of further growth by attracting and accommodating more people from surrounding area. Quantitatively, it is proved that towns grow (in terms of area and population) as a consequence of the availability of facilities of varying importance. Since a town grows, it is evident, its sphere of influence also increases progressively which leads to regional socio-economic development. Therefore, in order to accomplish the dual objectives of making an urban centre more beautiful as well as convenient for living, and not to leave any rural part out of the urban functional influence as well as to 
achieve balanced regional socio-economic development in the study area, aforementioned planning recommendations should be adopted and implemented. In addition, detailed field study at household level in each urban centre should be conducted to evaluate the existing level of living and quality of life of inhabitants, transportation and communication facility, level of pollution, drainage pattern and other civic amenities and facilities. Such a pragmatic study is imperative for city planning formulation and policy making to enhance quality of life as well as level of living and human well-being as well as welfare.

\section{References}

ABERCROMBIE, P. (1945), Greater London Plan - 1944, London, HMSO.

AHMAD, A., ALI, M., J. (2006), Levels of urbanization in West Bengal: A quantitative approach, Geographical Review of India, 68, pp. 407- 416.

ALI, M., J., MUSTAQUIM (2007), Growth of urban population and trends of urbanization in North Bengal, India: A study in spatio-temporal perspective, Asian Profile, 35, pp. 221-236.

ALI, M., J., ET AL. (2008), Population explosion and dynamics of urbanization: a case study of West Bengal, Man in India, 88, pp. 567-583.

BHAGAT, R., B. (2005), Urban growth by city and town size in India, paper presented in the Annual Meeting of Population Association of America, Philadelphia, U.S.A.

BHAGAT, R., B. (2002), Challenges of rural-urban classification for decentralized governance, Economic and Political Weekly, 37, pp. 2413-2416.

CENSUS OF INDIA (2001), Ministry of Home Affairs, Government of India, New Delhi.

GEYER, H., KONTULY, T. (1993), A theoretical foundation for the concept of differential urbanization, International Regional Science Review, 17, pp. 157-177.

GLASSON, J. (1978), An introduction to regional planning, Anchor Press Ltd., Great Britain, Tiptree Essex ( $\left.2^{\text {nd }} E d.\right)$.

HOSELITZ, B., F. (1971), The role of urbanization in economic development: some international comparisons, in D. J. Dwyer (eds.), The city in Third World, Mac Millan, London.

LAMPARD, E., E. (1955), The history of cities in economically advanced areas, Economic Development and Cultural Changes, p. 3.

LOKHANDE, T., N., PAWAR, C., T. (2004), Comparative analysis of service areas of market centres in Kolhapur district, Maharashtra, Geographical Review of India, 66, $\mathrm{p}$. 41.

MAHMOOD, A. (2002), Statistical methods in geographical studies, Rajesh Publications, New Delhi.

MAITHINI, B., P. (1986), Spatial analysis in micro-level planning, Om Sons Publications, New Delhi and Guwahati.

MANDAL, R., B. (2000), Urban geography - a text book, Concept Publishing Company, New Delhi, pp. 296-367.

MILLS, E., S., BACKER, C., M. (1986), Studies in Indian urban development, Oxford University Press, New York.

MOHAN, R. (2007), Urbanization and globalization in the twenty first century: emerging

challenges, presented as plenary address at Reserve Bank of India on July 2, at the Rockefeller Foundation's Urban Summit at Bellagio, Italy.

MUMFORD, L. (1961), The city in history, New York.

MURPHY, E., E. (1974), The American city: an urban geography, McGraw Hill, New York ( $\left.2^{\text {nd }} E d.\right)$.

NAGIA, S., AHLUWALIA, D. (2003), Hierarchy of urban settlement in Northern

Upper Ganga Plain, Indian Journal of Regional Science, 35, pp. 27-35.

NEVILL, H., R. (1926), Aligarh: a gazetter, Part-VI, Lucknow. 
PASCIONE, M. (2001), Urban geography: A global perspective, Routledge, London.

PAWAR, C., T., LOKHANDE, T., N. (2001), Centrality and hierarchy of market centres in Kolhapur district, Maharashtra, The Deccan Geographers, 39, pp.1-14.

Delhi.

POSSEHL, G., L. (1979), Ancient cities of the Indus, Vikas Publishing House, New Calcutta.

RAO, PRAKASH, V., L., S. (1964), Towns of Mysore State, Asia Publishing House, SHARMA, R., C. (1972), Settlement geography of Indian desert, Kumar Brothers, Hauz Khas, New Delhi.

STAMP, L., D. (1941), Land reclamation in relation to new towns, The City Planning, 9 pp. 14-15.

THAKUR, R. (1994), Urban hierarchies, typologies and classification in early medieval India: c 750-1200, Urban History, 21, pp. 61-76.

THAKUR, R. (2002), Mechanisms of urban growth in India: AD 600-1200, Urban History, 29, pp.187-196.

TIWARI, V., K., ET AL. (1986) eds., Indian cities: ecological perspectives, New Delhi.

UNITED NATIONS (2001), World urbanization prospects: The 1999 revision, Population

Division, Department of Economic and Social Affairs, U.N., New York.

VERMA, L., N. (2006), Urban geography, Rawat Publication, Jaipur (India), p. 98.

www.idealcity.org.au

www.globalissues.org/news/2012/04/05/13247

YASENOVSKIY, V., HODGSON, J. (2007), Hierarchical location-allocation with spatial choice interaction modeling, Annals of the Association of American Geographers, 97, pp. 469511.

YUEN, BELINDA (2009), Revisiting urban planning in east Asia, south-east Asia and the Pacific, Regional study prepared for planning sustainable cities: global report on human settlements, Singapore, p. 28.

Initial submission: 17.08 .2012

Revised submission: 31.10 .2012

Final acceptance: 30.11 .2012

Correspondence: Department of Geography, Aliah University, Dn - 47, Sector - V, Salt Lake City, Kolkata - 900091, India.

Department of Geography, Aligarh Muslim University, Aligarh, U.P. 202002, India.

E-mail: julfikar21@gmail.com, varshney.deepika@gmail.com 